材料科学での中性子の新しい使い方 : 白色中性子ホログラフィー

大山 研司，林 好一*

(茨城大学 理工学研究科, 名古屋工業大学 工学研究科 ${ }^{*}$ )

\title{
Novel Usage of Neutrons: White Neutron Holography
}

Kenji Ohoyama and Kouichi Hayashi*

Graduate School of Science and Technology, Ibaraki University and Graduate School of Technology, Nagoya Institute of Technology*

\section{0}

\begin{abstract}
In this article, the novel neutron technique, white neutron holography, is introduced. White neutron holography is an indispensable probe for local atomic structures around dopants in functional materials. The advantages, brief principle, and recent results are explained. We believe that white neutron holography will be a novel probe which characterizes materials science in J-PARC.
\end{abstract}

Keywords: local atomic structure, functional materials, white neutron holography

1. 材料科学でのホログラフィーの役割

J-PARC では世界最高峰の装置群が輝かしい成 果をあげているが，この小文では，それら J-PARC 装置とは少々異なる新しい中性子の使い方として, J-PARC オリジナルの手法である白色中性子ホロ グラフィーを紹介したい.

J-PARC の中性子実験では, ラジオグラフィーを 除けば Qて，これは物質中の空間的周期性に対する物理量 を測定していることを意味する。一方で，機能性 材料においては結晶中の非周期構造が決定的な役 割を果たしている場合がある。たとえば， Si 半導 体では，B や P など異種元素をわずか $10^{-3} \sim 10^{-7} \%$ 程度ドープすることで抵抗率が何桁も変化するこ とを利用して半導体製品として機能させている. 不純物ドープがキャリアドープに対応寸るのはも ちろんだが，構造物性の視点では，ドーパント周 りの原子構造がどのように変化したのか，が重要 であることは容易に想像できる。

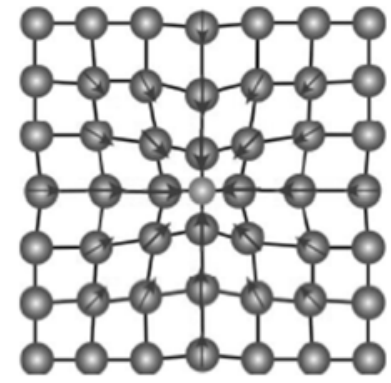

Fig.1. Local atomic structure around a dopant, which is slightly distorted from the average structure.
Fig. 1 は異種元素ドープによる周囲の原子構造 の変化のイメージ図である。このようなドーパン 卜まわりの構造をここでは局所構造と呼ぶ。この 局所構造が機能性発現の鍵であろうし，そもそも ドーパントが格子中のどの位置に入るのかも局所 構造観測によって決定することができる.しかし， Fig. 1 の孤立した局所構造には並進対称性がない ため，通常の回折法は局所構造観測には無力であ る.したがって，ドープによる局所構造の変化， あるいはドーパントの位置の確定は，その重要性 にもかかわらず十分とは言えなかった。

この局所構造の観測に有効な手法のひとつが原 子分解能ホログラフィー(以下, ホログラフィー) である $[1,2]$. ホログラフィーは放射光 $\mathrm{X}$ 線, 光電 子線を用いてすでに広く用いられており，他の原 子観測手法，たとえば，通常の回折法，二体分布 関数 $(\mathrm{PDF})$ 法, $\mathrm{X}$ 線吸収微細構造 $(\mathrm{XAFS})$ 法な どと比べ, 以下の重要な強みがある.

1) 試料中の特定の元素（ドーパント）の周囲の みを選択的に観測できる

2) ドーパント周りの局所構造を三次元でモデル なしで可視化できる.

3) 中心原子から約 $20 \AA$ の範囲を可視化可能で, 局所構造から平均構造への変化を観測できる.

元素選択的観測は回折法, PDF 法にはない強み であり，また局所構造観測の代表的手法である XAFS 法と比べても 2)，3)は大きな利点である. モデルなしに直接三次元像を可視化できることか ら, ホログラフィーは原子イメージング法とも言 
える、このような利点を生かし，日本においては 放射光 $X$ 線, 電子線を用いて局所構造研究に活発 に利用されているおり, 寸でに, 希薄磁性半導体, リラクサー, トロポジカル絶縁体, 超伝導体など で独創的な成果があがっている[3-9]. ホログラフ イーが決定的な役割を果たした一例として， $\mathrm{TiO}_{2}$ 薄膜での室温強磁性について簡単に紹介寸る. 半 導体 $\mathrm{TiO}_{2}$ 薄膜に $\mathrm{Co}$ を $5 \%$ 程度ドープすると， $T_{\mathrm{C}}$ $600 \mathrm{~K}$ をも室温強磁性状態が発現することが知 られており [10], 当然 Co と周囲の環境の変化の理 解が重要となるが，電子顕微鏡では構造の異常は 観測されなかった。 そこで $\mathrm{Hu}$ らは蛍光 X 線ホロ グラフィーにより Co 周りの原子構造を可視化し, Co を $1 \%$ ドープした常磁性 $\mathrm{TiO}_{2}$ では，単純にル チル型構造のまま Ti と Co が置換しているのに対 し， Co を $5 \%$ ドープした強磁性 $\mathrm{TiO}_{2}$ では, $\mathrm{Co}$ 近 傍の原子構造が $\mathrm{CoO}_{2} \mathrm{Ti}_{4}$ と同じ亜酸化物構造をと る事を明らかにし，この亜酸化物構造がルチル型 $\mathrm{TiO}_{2}$ 内で安定化することが強磁性発現の鍵となる ことを見事に示した[3]. これは，ドーパントが原 子構造に与える影響を観測することで，物性の起 源を解明できた好例といえよう。

一方で， X 線，電子線では $\mathrm{B}$ などの軽元素を 高精度で観測することができないため, 長い研究 と利用の歴史がある $\mathrm{Si}$ でさえ, ドープされた B が 格子のどこにいるのかは実験的には検証されてい なかった。（もちろん，B が Si 位置にはいること は周知のことではあるが. ) 一方で, 近年の機能性 材料においては，H， Li， B などの軽元素が重要な 役割を果たしていることから，中性子でのホログ ラフィーが材料科学にとって必要となる.

中性子ホログラフィーは, 2001 年にハンガリー のCser らにより提案され，同年に Sur らによって Chalkriver 研究所において最初の実験が成功して いる[11,12]. 国内では2008 年に筆者らにより JRR3 の単色中性子を用いて $\mathrm{PdH}_{0.76}$ 単結晶での水素ま わりの局所構造の観測に成功している[13]. しか し，これまでの中性子ホログラフィーでの原子像 は精度が不十分であった。ホログラフィーの原理 的な特徵として, 単一波長のみでの測定ではかな らず真の原子位置と対称な位置に偽の原子像が生 じ，これが再生原子像を劣化させてしまうからで ある[2]. 原子像の信頼性を高めるには，複数の波 長での測定が必須であり，実際，放射光でのホ口 グラフィー実験では 5 10 の波長で測定し, 全部 のデータを統合して解析する. しかし原子炉での 中性子実験では JRR-3 の例でいえば 1 波長の測定 でも約 4 日かかり[13], 複数波長測定は現実的で はないため, 過去の中性子ホログラフィー実験は デモ測定にとどまっていた。

中性子での多波長ホログラフィー実験を実現し, 原子像の信頼性を劇的に向上させたのが，2017年 に筆者が開発した「白色中性子ホログラフィー」 である $[14,15]$. J-PARCでの白色中性子とイベント 処理を最大限活用することで, 1 度の測定で最大 130 の異なる波長での測定を可能にし，後述する
$\mathrm{Eu}$ ドープ $\mathrm{CaF}_{2}$ での局所構造を高精度で可視化す ることに成功した[14]. 使用する波長の数は原子 像の信頼性に直結寸ることから, 白色中性子小口 グラフィーでの原子像の精度が放射光 X線でのそ れを凌駕する可能性すら秘めている. 実際, これ までの経験では, 中性子での原子像の方が放射光 $\mathrm{X}$ 線での原子像よりも明瞭であることが, 重元素 であっても起きている，その意味でも，白色中性 子ホログラフィーは J-PARC を特徵づける新たな 顔の一つになりうると期待している。 また, JPARC と放射光施設でのホログラフィー実験の試 料サイズはもちろん大きく異なるものの，1つの 試料の測定に必要なマシンタイムはどちらも約二 日である. 同じ時間で同程度の精度の結果が得ら れることから, 中性子と放射光 X 線のホログラフ イーは, 同格の存在感をもつ相補的利用の好例と なる。

\section{2. 白色中性子ホログラフィーの原理}

Fig. 2 は J-PARC で行われている白色中性子小 ログラフィーの原理図である $[14,15]$. 基本的には 放射光施設での蛍光 $\mathrm{X}$ 線ホログラフィーのインバ ースモードと同じ原理である[2]. 入射中性子ビー ムは平面波であり, 試料中の原子 $\mathrm{B}$ などで散乱さ れ球面波が生じる。この球面波と別の球面波の遠 方での干渉がブラッグ反射を生むが，原子 B で生 じた球面波は入射平面波ともわずかに干渉を起こ しており，試料中に定在波が生じる。この定在波 には原子 B の位置情報が含まれており, もし原子 $\mathrm{A}$ の位置でこの中性子定在波の強度を観測するこ とができれば, 原子 A からみた原子 $\mathrm{B}$ の位置を決 定できる. 原子 $\mathrm{A}$ 近傍のどの原子も同様の定在波 をつくるので, 結局, 定在波を測定できれば原子 $\mathrm{A}$ 周りの局所構造が観測できる.

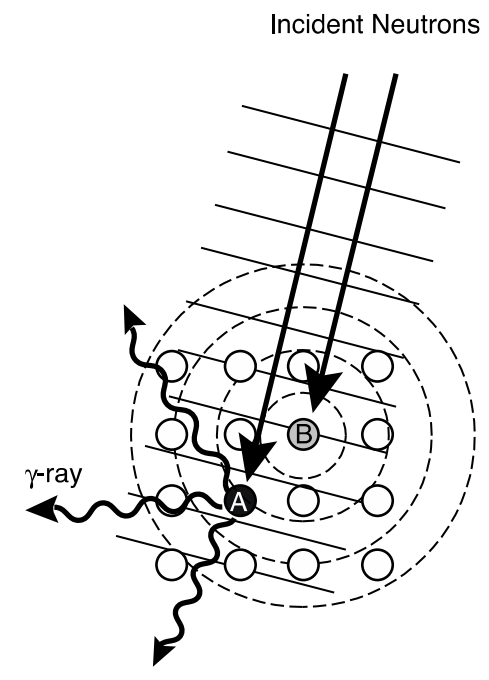

Fig. 2. Principle of white neutron holography. A is the dopant. 
問題は原子 $\mathrm{A}$ 位置のみの定在波強度をどう測定す るか，である。ドーパントである原子 A がホウ素 や $\mathrm{Eu}$ のように吸収断面積の大きい元素である場 合, 中性子吸収によりドーパントから即発ガンマ 線（Fig. 2 の波線）が等方的に発生する. このガン マ線の強度は原子 $\mathrm{A}$ 位置の中性子強度に比例し, その中には定在波の成分も含まれている. B や Sm などであれば即発ガンマ線強度は他の元素, たと えば Si からの即発ガンマ線よりも圧倒的に強い ので，この強度差が元素選択性を保証する。この 原子 $\mathrm{A}$ からのガンマ線強度を試料を回転させなが ら測定し，それを $\mathrm{k}$ 空間で球体に貼り付けたのが

「ホログラム」である. ホログラム $\chi(\vec{k})$ は以下の ように表される。

$$
\chi(\vec{k})=2 \sum_{i} \frac{b_{i}}{r_{i}} \cos \left(k r_{i}-\vec{k} \vec{r}_{i}\right)
$$

ここで, $\vec{k}$ は入射ビームの波数ベクトル $(k=2 \pi / \lambda)$ だが，ホログラフィーでは向きを入射ビームと反 対にとる。この $\vec{k}$ をホログラム上の位置べクトル とするためである。 $r_{\mathrm{i}}$ と $b_{\mathrm{i}}$ は $\mathrm{i}$ 番目の原子とドー パントとの距離とその原子の核散乱長である。(1) 式からわかるように，ホログラフィー実験では散 乱ベクトルは意味をもたない.

Fig. 3(a)は中性子ホログラフィー実験で得られ た中性子ホログラムの例で, 標準試料として Cu単 結晶を用いた。この場合は，ドーパントではなく 各 $\mathrm{Cu}$ 周囲の歪みのない原子像を観測しているこ とになる.Fig. 3(a)で幾何学的な模様が観測されて おり，これが中心原子周りの原子構造を反映して いる. Fig. 3(b)は半径 $100 \AA$ の $\mathrm{Cu}$ クラスターモデ ルから得られたホログラムのシミュレーション結 果で, Fig. 3(a)と 3(b)の幾何学模様は細部までよく 一致しており, Fig. 3(a)のホログラムには原子構造 が観測されていることがわかる。

Fig. 3(a)のようなホログラムから原子像を得る には，Barton 法とよばれる以下の式を用いる $[14,15]$.

$$
U(\vec{R})=\sum_{k} e^{i k R} \int_{\sigma} \chi(\vec{k}) e^{-i \vec{k} \vec{R}} d \sigma
$$

ここで, $\vec{R}$ は実空間での位置ベクトル $\mathrm{d}$ 。はホロ グラム上の微小面積である. 白色中性子ホログラ フィーの場合，広い範囲の值をもった多数の $k$ を 用いている. 初期状態である平面波を干渉に用い るため, 回折実験での位相問題がここには含まれ ないことが重要で，モデルなしに直接実空間での 核散乱長分布，すなわち原子像が得られる。当然 ながら，三次元原子像を得るには三次元の $\chi(\vec{k})$ が 必須なので, 試料が単結晶である必要がある。

Fig. 3 は $=1.65 \AA$ でのホログラムなので，いわ ば薄皮一枚の球体だが，白色中性子ホログラフィ 一のホログラムは, $k$ の大きさ（ホログラムの半 (a)

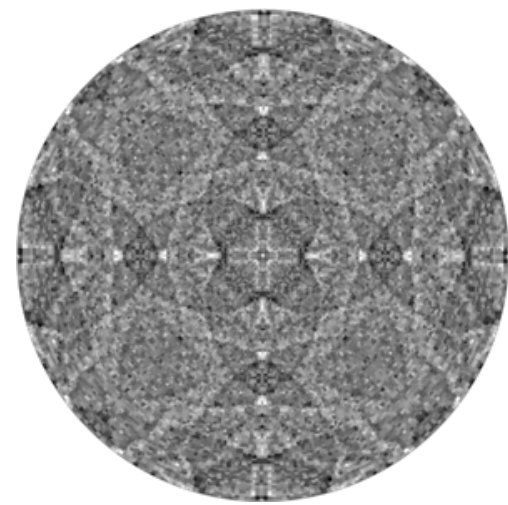

(b)

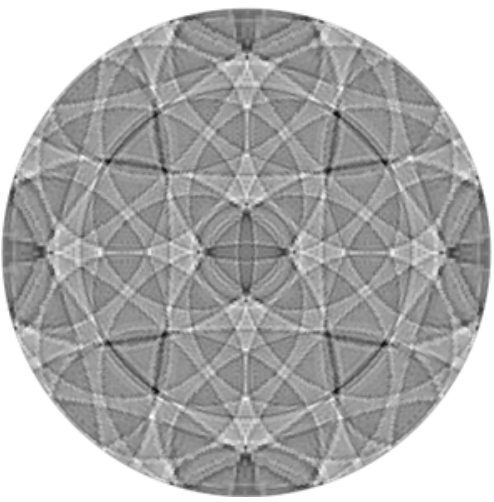

Fig. 3. An obtained neutron hologram of $\mathrm{Cu}$ with $\lambda=1.65 \AA$. (a) Experiment, (b) Simulation.

径）に十分な幅があるため，厚みのあるホログラ ムとなる。三次元原子像を得る上で，薄皮一枚の データと十分な厚みがあるデータとでどちらが有 利か，は明らかであろう。これが白色中性子を用 いることで高精度の原子像が与えられる理由の一 つである。

測定は，J-PARCの BL10 で装置グループの全面 的な協力を得て行なっている. 測定はシンプルで, $\omega$ - $\phi$ 二軸ゴニオで試料を回転させ, 試料からでる ガンマ線を検出し, Fig. 3 のホログラムを得る.こ のとき $\omega$ 軸は鉛直, $\phi$ 軸は水平に置いてある. 試料 と検出器の距離は約 $100 \mathrm{~mm} \sim 170 \mathrm{~mm}$, 線源から 試料までの距離は $14.0 \mathrm{~m}$ である. 測定は $\omega$ 角を固 定し $\phi$ 軸を連続で $360^{\circ}$ 回転する過程を繰り返す. 角 度と強度は TrigerNet を用いたイベント処理で結 びつき，ホログラムが得られる，典型的な実験で の $\omega$ 角の範囲は $10^{\circ}$ から $170^{\circ}$ で, 放射光 $\mathrm{X}$ 線では 装置の構造上の制約から $0^{\circ}-75^{\circ}$ 程度であるのと比 ベると，より広い範囲でデータが得られる。この ことは対称の低い構造での解析で非常に重要であ り, 中性子ホログラフィーの強みである. 必要な 試料サイズは，B ドープ試料ならば $5 \mathrm{~mm}$ 角程度 の試料で成功例がある.

ホログラフィー実験装置の特色として，高精度 の原子像を得る上で他の分光器や回折装置のよう 
な意味での高分解能は必要ない, という点が挙げ られる. 多数の波長でホログラムを作る際には， いわばある波長幅で $I(\lambda)$ を切り取りその範囲の力 ウントを積分してデータ化しているため, モデレ 一ター上でのパルス形状は直接的には原子像に反 映されない。また，ドーパントから等方的に発生 する即発ガンマ線を検出するため, 試料一検出器 間の角度分解能も不要で, 逆にひたすら立体角を 大きくする方が効率的である. この意味で, 白色 中性子ホログラフィー装置は比較的作るのが簡単, と言えるかもしれない.ただし，中性子ホログラ フィーは生まれたばかりの手法であり, 装置パラ メーターの何が原子像の精度に最も重要なのか, は今後検討していかなければならない。

\section{5. 最近の成果}

白色中性子ホログラフィーの成果として，B ド 一プ $\mathrm{Si}$ と代表的シンチレーション結晶 $\mathrm{CaF}_{2}$ での 結果を簡単に紹介する. Fig. 4 は白色中性子ホロ グラフィーで可視化した 0.26 at $\%{ }^{10} \mathrm{~B}$ doped $\mathrm{Si}$ で の $\mathrm{B}$ (中央) 周りの局所原子構造である [15]. 通常 の結晶構造ではなくて， $\mathrm{B}$ 周りにだけ存在する局 所構造であることに注意いただきたい. Fig. 4 か ら, $\mathrm{B}$ 周りの $\mathrm{Si}$ はダイアモンド構造をとっている ことが確認され，B は確かに Si と置換しているこ とが示された。これはすでに広く知られているこ とではあるが，実験的な証拠が得られたのはこの 白色中性子ホログラフィー実験が初めてであり, 予想通りではあってもその重要性は理解いただけ ると思う。また，わずか 0.26 at \%の含有量の元素 から情報が得られる，ということも中性子として は驚異的なことである。

Fig. 5 は代表的シンチレーション結晶である $\mathrm{Eu}$ ドープ $\mathrm{CaF}_{2}$ での $\mathrm{Eu}$ (中央) 周りの局所構造であ る[14]. Fig. 5A が測定結果から得た $\mathrm{Eu}$ 周りの原 子像, Fig. 5B は母物質 $\mathrm{CaF}_{2}$ での $\mathrm{Ca}$ 周りの原子像

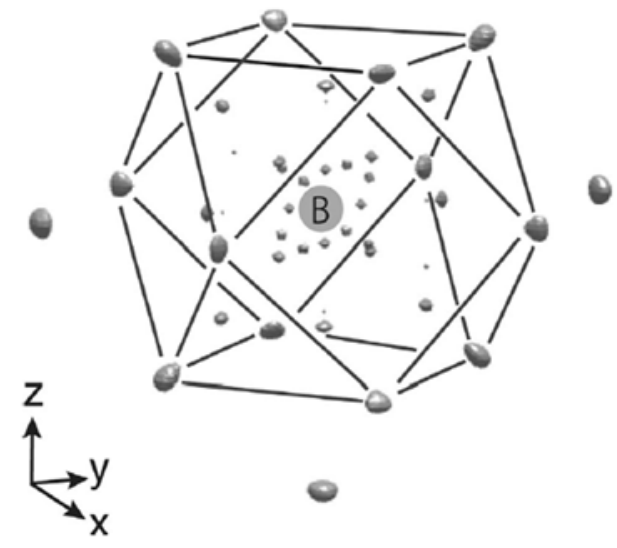

Fig. 4. Local atomic structure around B in 0.26 at $\%$ B doped Si.( Reproduced from Figure 14 of ref. 15 with permission. Copyright Wiley-VCH Verlag GmbH \& Co. KGaA.)
のシミュレーションである. Fig. $5 \mathrm{~A}$ の $\mathrm{Eu}$ 周りの 構造が Fig. 5B のシミュレーションと一致するこ とから, Eu は Ca 位置に入ることがわかる.一方， $\mathrm{CaF}_{2}$ 中の $\mathrm{Eu}$ は三価になっていることがわかって いるため, $\mathrm{Eu}^{3+}$ が $\mathrm{Ca}^{2+}$ と置き換わるならば電気的 中性が問題となる. Fig. 5A の原子像の詳細な解析 から， $\mathrm{Eu}^{3+}$ から $2.3 \AA$ 離れた位置に過剒な $\mathrm{F}^{-}$が存 在していることがわかり，これが電気的中性を担 保していることが明らかになった。過剩 Fにより 電気的中性が維持されるというのは古くから指摘 されていたことだが，これも実験的に観測された のは初めてである。また，ドープ効果として興味 深いことも観測された. Fig. 5A と 5B を比べた結 果, Euにもっとも近い F サイトはドープの影響を あまり受けていないのに対し, その外側にある $\mathrm{Ca}$ サイト（Fig. 5A 中の丸）は大きく摇らいでおり, そのため Fig. 5A では第 2 近接 $\mathrm{Ca}$ では明瞭な原子 像が得られない. すなわち最近接よりも第 2 近接 の原子にドープ効果が強く現れていることになる。 これは異元素ドープが格子に与える影響は単純で はなく, 直接観測することの重要さを示している.

ここでは二つの例のみを挙げたが，すでに白色 LED 材料 $\mathrm{SiC}$, 熱電材料 $\mathrm{Mg}_{2} \mathrm{Si}$, 強相関電子系 $\mathrm{RB}_{6}$

（R: $\mathrm{Yb}, \mathrm{La}, \mathrm{Tm})$ など様々な物質でのドーパント 周りの原子像の可視化に成功しており,特に $\mathrm{SiC} と$
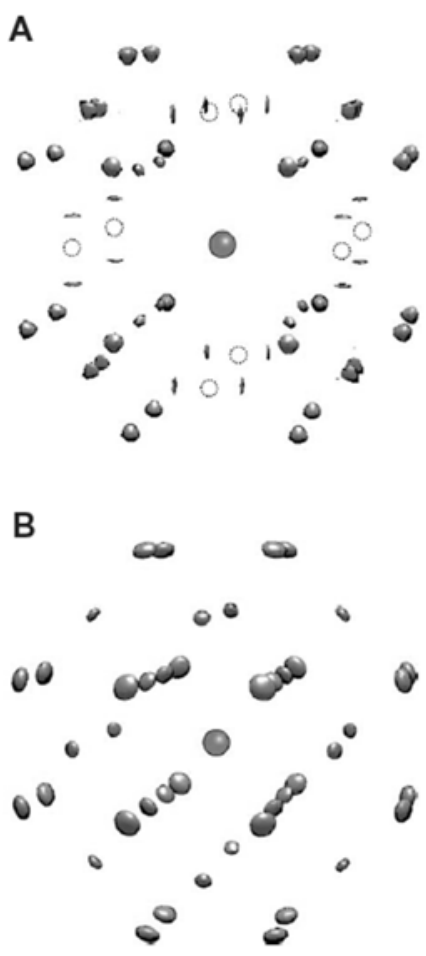

Fig. 5. Local atomic structure around $\mathrm{Eu}^{3+}$ in $\mathrm{CaF}_{2}$. (A) Reconstructed images from the experiments, (B) Reconstructed images from simulation (Reproduced from Figure 4 of ref. 14 with permission) 
$\mathrm{Mg}_{2} \mathrm{Si}$ では B の位置を世界で始めて決定すること ができた。

現在のところ，中性子ホログラフィーで対象に なるドーパントは ${ }^{10} \mathrm{~B}, \mathrm{Eu}, \mathrm{Sm}, \mathrm{Cd}$ など,中性子では 忌み嫌われる元素である. これらの元素からのガ ンマ線は強いので，元素選択性を保証できる。し かし，ホログラフィーをより広く応用するには， 吸収の比較的弱い，したがって即発ガンマ線の弱 い元素に取り組む必要がある。その場合に元素選 択性を保証するためには，ガンマ線エネルギー分 解能の高い $\mathrm{Ge}$ 検出器を用い, 元素ごとの即発ガ ンマ線を分解することで原理的には対応できる. 高ガンマ線エネルギ一分解能でのホログラフィー 実験は現在，開発を進めている。

\section{6. 今後の展開}

白色中性子ホログラフィーは，現段階では筆者 らのみが, 寸なわちJ-PARCでのみ成功している. この材料科学での J-PARC の特色あるリードを維 持するために，さらに技術的に進展させていきた いと考えている. まだまだ技術的な課題は多いも のの，「見えるか見えないか」という第 1 段階は乗 り越えつつある。第 2 段階として，原子像の定量 的評価に取り組んでいる。たとえば，異種元素ド 一プにより近接の原子は多かれ少なかれ動的また は静的なゆらぎが生じることが予想される。その ような隣接原子のゆらぎは，原子像の強度の低下 と原子像の幅の拡大として観測できる。これは回 折実験や散漫散乱で観測している平均的なゆらぎ とは異なり，ドープによって生じた局所的なゆら ぎである．定量的な解析の精度が高まれば，格子 に対するドープ効果をより詳細に議論することが できる。

さらに，新たな，そして野心的な挑戦として， 水素でのホログラフィーおよび磁気ホログラフィ 一の開発を 2019 年度より始めている.また，水素 化物の場合，水素脆化により単結晶は期待できな いため，粉末試料でのホログラフィーにも取り組 み始めた。粉末での測定に成功すれば様々な材料 に適用できるので，中性子ホログラフィーが XAFS 法のように材料科学に久かせない手法とな ると期待している。

\section{謝辞}

本研究では多くの方のご協力をいただいている が，特に J-PARC の原田氏と及川氏，および稲村 氏の全面的なサポートにより実現することができ た。紙面をお借りしてお礼申し上げたい.

ホログラフィー開発では主に新学術領域「3D 活 性サイト」（課題番号：26105006）の支援をいただ いた。また，2019年度より，水素化合物でのホロ グラフィーは新学術領域「ハイドロジェノミクス」 （課題番号 : 19H05045）の，磁気ホログラフィー は科研費基盤 A（課題番号：19H00655）のご支援 をうけ，実験を開始している。
参考文献

[1] A. Szöke, in Short Wavelength Coherent Radiation: Generation and Applications, AIP Conf. Proc. No. 147, edited by D. T. Attwood and J. Boker (American Institute of Physics, New York, 1986).

[2] K. Hayashi and P. Korecki, J. Phys. Soc. Jpn. 87, 061003 (2018).

[3] W. Hu et al., Appl. Phys. Lett. 106, 222403 (2015).

[4] W. Hu, et al., Phys. Rev. B 89, 140103(R) (2014).

[5] K. Hayashi et al., J. Appl. Phys. 119, 125703 (2016).

[6] Y. Wakabayashi et al., Phys. Rev. B 93, 245117 (2016).

[7] A. Sato-Tomita, et al., Rev. Sci. Instrum. 87, 063707 (2016).

[8] T. Yamamoto, et al., Acta Mater. 130, 534 (2017).

[9] S. Hosokawa et al., Phys. Rev. B 96, 214207(2017).

[10] Y. Matsumoto et al., Science 291, 854 (2001).

[11] L. Cser et al., Phys. Rev. Lett. 89, 175504 (2002).

[12] B. Sur et al., Nature 414, 525 (2001).

[13] K. Hayashi et al., Jpn. J. Appl. Phys. 47, 2291 (2008).

[14] K. Hayashi et al., Sci. Adv., 3, e1700294 (2017).

[15] K. Ohoyama and K. Hayashi, Phys. Status Solidi B 255, 1800143 (2018). 